\title{
An Overview of the Vine Mealybug (Planococcus ficus) in South African Vineyards and the Use of Entomopathogenic Nematodes as Potential Biocontrol Agent
}

\author{
P.D. le Vieux*, A.P. Malan
}

Department of Conservation Ecology and Entomology, Stellenbosch University, Private Bag X1, Matieland 7602, South Africa

Submitted for publication: December 2012

Accepted for publication: February 2013

Key words: entomopathogenic nematodes, grapevines, Heterorhabditidae, integrated pest management, mealybug, Planococcus ficus, Steinernematidae

\begin{abstract}
The vine mealybug, Planococcus ficus (Hemiptera: Pseudococcidae), which is the dominant mealybug species in South Africa, is a severe wine and table grape pest and disease vector. Their increasing resistance to chemical pesticides and cryptic lifestyles have led to the search for new control methods. Entomopathogenic nematodes (EPNs) belonging to the families Heterorhabditidae and Steinernematidae are deadly insect pathogens. This paper gives valuable background information on $P$. ficus and EPNs, while paying particular attention to the potential use of South African EPN species as biocontrol agents against $\boldsymbol{P}$. ficus.
\end{abstract}

\section{Vine Mealybug: Planococcus ficus (Signoret)}

The mealybug family (Hemiptera: Pseudococcidae) is large, consisting of more than 240 recorded and described species that are categorised in almost 300 genera (Millar, 2002; BenDov \& Miller, 2012). In South Africa, a total of 50 genera and 109 species have been recorded, of which 13 genera and 68 species are indigenous (Millar, 2002).

The general common name 'mealybug' is derived from the white mealy or powdery wax that these species secrete to cover their bodies (Millar, 2002; Franco et al., 2009). Mealybugs are all phytophagous, with vine mealybugs specifically being phloem feeders (Millar, 2002; Daane et al., 2006). They are very small, soft-bodied insects with piercing, sap-sucking mouthparts. They encourage the growth of sooty mould on vines and grapes by producing a substrate of sticky honeydew (Millar, 2002; Franco et al., 2009). Mealybugs are considered severe agricultural pests, as their presence and feeding cause direct damage to plants by lowering production and rendering fruit unmarketable, while also transmitting various plant viruses (Greiger \& Daane, 2001; Holm, 2008). Various studies have shown Planococcus ficus (Signoret) (Hemiptera: Pseudococcidae) to be the dominant mealybug species in South African vineyards, highlighting the demand for attention and need for control (Kriegler, 1954; Walton \& Pringle, 2004b).

\section{History and geographical distribution}

The vine mealybug, P. ficus, has been subject to repeated renaming, misidentification and reclassification in the past, due to the lack of qualitative characteristics to help distinguish it from other, similar species (Walton, 2003). Currently there still are various colloquial names in use that could easily lead to confusion. For instance, common names of the species given by De Villiers (2006) include both vine mealybug and grapevine mealybug, whereas Walton and Pringle (2004b) and Holm (2008) both provide another two vernacular names, the subterranean vine mealybug and the Mediterranean vine mealybug. Henceforth in the current document, the name vine mealybug will be used, bearing in mind that the species must not be mistaken for the closelyrelated grape mealybug, Pseudococcus maritimus (Ehrhorn).

The first South African vine mealybug sighting was recorded in 1914 (Holm, 2008). The mealybug in question was originally identified as Planococcus citri (Risso), and subsequently correctly identified as P. ficus in 1975 (Walton \& Pringle, 2004b; Holm, 2008). Planococcus ficus, which was first recorded as being a problem in the vineyards of the Western Cape province in 1930, had spread to the Hex River Valley by 1935 , as well as to all other major vineyards in the Western Cape (Walton, 2003; Walton \& Pringle, 2004b; De Villiers, 2006; Holm, 2008). It is currently regarded as a key pest insect of the South African table grape and wine industries. It is uncertain how and when P. ficus was introduced to South African agriculture, and where it originates from. Presumably being native to the Mediterranean region, it is assumed to have entered the South African system via plant material (Walton \& Pringle, 2004b; De Villiers, 2006). Internationally it has spread and caused damage to vineyards

*Corresponding author: E-mail: plevieux@sun.ac.za

Aknowledgements: The authors would like to thank Winetech and the Technology and Human Resources for Industry Programme, for funding the project 


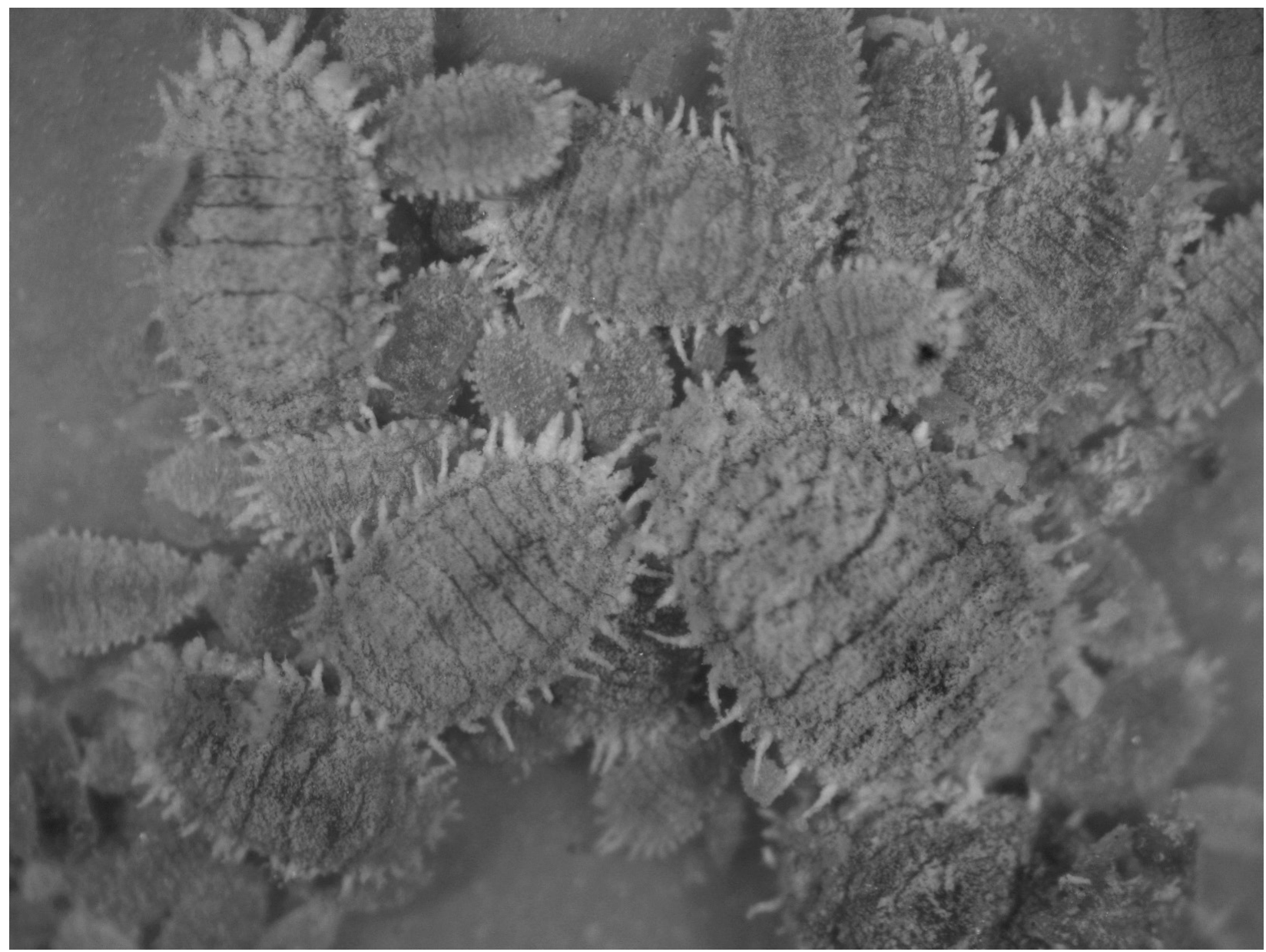

FIGURE 1

A colony of female Planococcus ficus.

in the Middle East, Pakistan, South America, California, the Mediterranean region, Mexico, Europe and North Africa, among other areas (De Villiers, 2006; De Villiers \& Pringle, 2007; Daane et al., 2008).

\section{Morphology and life cycle}

Mealybug species are difficult to distinguish due to their close resemblance to one another and the lack of morphological description in earlier studies. For example, there are only minor differences in the arrangement and number of glandular ducts on the dermis of P. ficus and P. citri (Walton, 2003; Walton \& Pringle, 2004b). A number of efforts have been made to assist with mealybug identification. Millar (2002) has provided a key to help identify South African Pseudococcidae genera, while other authors, such as Wakgari and Giliomee (2005), have developed a detailed diagnostic key, including morphometric characters, to distinguish the six mealybug species found on citrus in South Africa.

Mealybug taxonomy is based mostly on the female anatomy, due to the short-lived, inconspicuous nature of the males (Millar, 2002; Holm, 2008). Millar (2002) expresses concern that, despite previous descriptive work already having been done, the identification of South African mealybugs, especially when they are in their nymphal or egg phases, still remains a challenge. Despite the difficulties experienced with morphological descriptions and identifications, molecular identification techniques have been developed to distinguish accurately between the different mealybug species. A molecular identification approach was successfully developed by Pieterse et al. (2010) to identify to species level any life stage of the seven most important mealybugs found on citrus in South Africa. In North America, a multiplex PCR molecular tool was developed by Daane et al. (2011) to identify seven different problematic mealybug species found in vineyards. Of the seven species concerned, individuals such as $P$. ficus, $P$. citri, Pseudococcus viburni (Signoret) (obscure mealybug) and Pseudococcus longispinus (Targioni-Tozzetti) (longtailed mealybug) are common pests in South African vineyards.

\section{Females}

Vine mealybugs, like most scale insects, are sexually dimorphic (Holm, 2008; Franco et al., 2009). Females are neotenic and wingless, weighing about 100 to 200 times more than the adult male (Holm, 2008). Adult female $P$. ficus are approximately $4 \mathrm{~mm}$ in length, slightly wider than $2 \mathrm{~mm}$ and approximately $1.5 \mathrm{~mm}$ thick. They are segmented, with a pink to slate-grey-coloured flesh that is covered by a fine white powdery wax layer. The fringe of the body has waxy hair-like extensions, while a thin dark line denuded of wax runs down the back of the body.

The female mealybug (Fig. 1) undergoes incomplete 


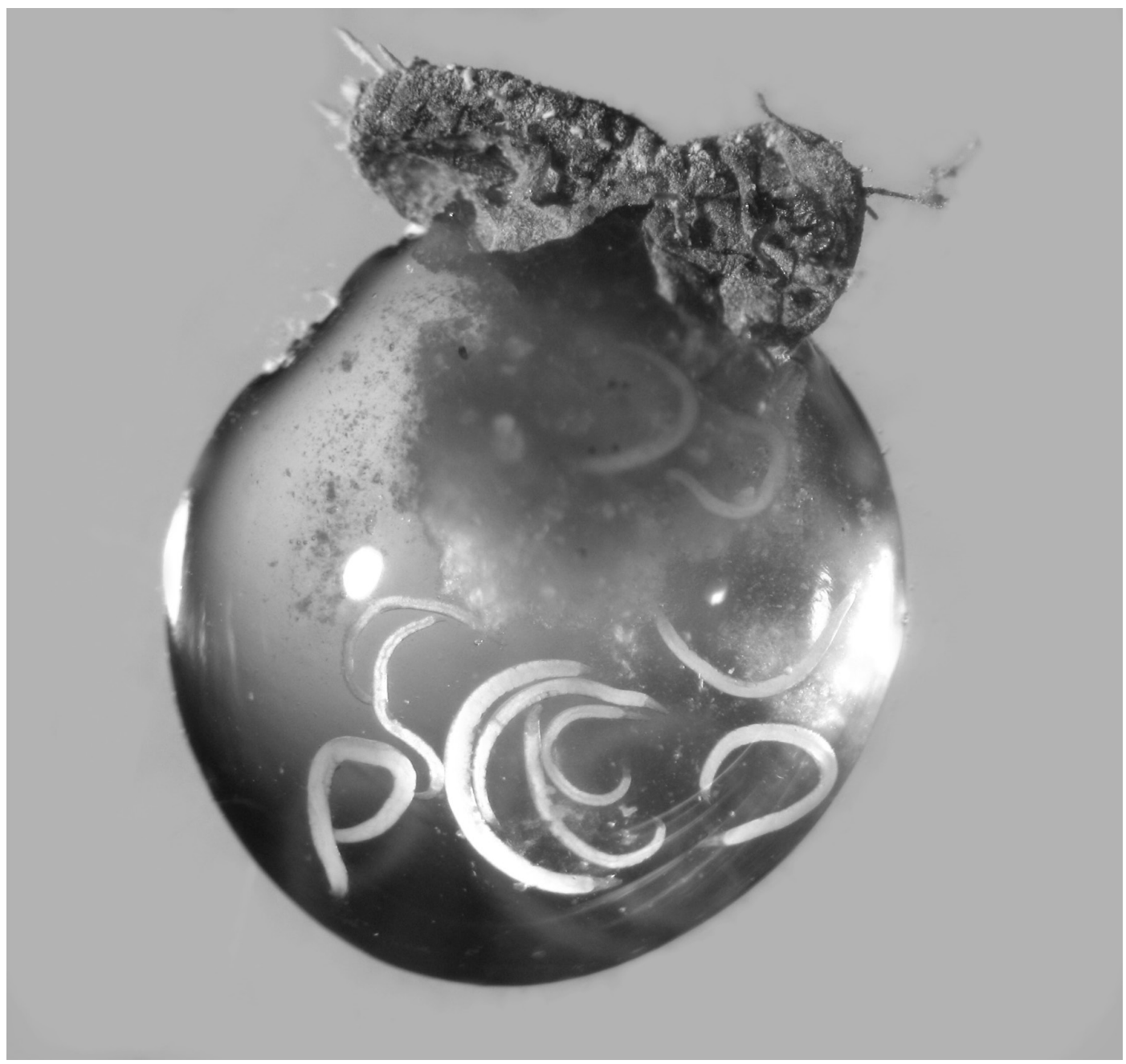

FIGURE 2

Dissected mealybug showing the developed nematodes in a drop of water (Stokwe \& Malan, 2010).

metamorphosis, passing through five growth stages, including an egg, three nymphal instars (crawlers) and, lastly, the adult (Picker et al., 2002; Walton \& Pringle, 2004b; Holm, 2008; Franco et al., 2009). After mating, each oviparous female lays an average of 362 eggs within white egg sacs or ovisacs constituted of filamentous waxy hairs (Walton, 2003).

\section{Males}

Male $P$. ficus adults are tiny, delicate, dipterous insects (Franco et al., 2009). They are less than $1 \mathrm{~mm}$ long and brownish in colour, with a pair of inconspicuous, transparent wings. They have beaded antennae, with a thorax that is wider than the abdomen (Dreves \& Walton, 2010). Planococcus ficus males have two long tail filaments (anal seta) to help with flight stabilisation, and no functional mouth parts. They have a short life span, with the single purpose of copulating with females who, at sexual maturity, release pheromones to attract the males (Walton \& Pringle, 2004b; Franco et al., 2009; Dreves \& Walton, 2010).

Male mealybugs go through complete metamorphosis, with distinguishing male characteristics becoming apparent after the third growth stage (Walton, 2003; Holm, 2008). Contrary to the female's five growth stages, males endure seven stages, which include eggs, three nymphal instars, pre-pupae, pupae and, lastly, the adult stage (Walton, 2003). Planococcus ficus, unlike $P$. maritimus, does not diapause through winter, resulting in all life stages being found in any given season, with populations in South Africa experiencing about five to six generations in any one year (Kriegler, 1954; Holm, 2008; Cid et al., 2010). The variations in generation numbers that have been observed in other countries are held by Walton and Pringle (2004b) to possibly be related to the mean temperature differences involved.

\section{Host plant range}

Planococcus ficus is a polyphagous insect that feeds on a wide range of host plants apart from just Vitis vinifera (grapevine) (Daane et al., 2008; Walton et al., 2009). Such feeding habits enable the provision of an unwanted source population of the pest outside of vineyards (Haviland et al., 2005). In California, P. ficus has been reported on subtropical and tropical crops, along with a few common weeds, whereas in Europe it is commonly found on fig trees (Ficus spp.) (Haviland et al., 2005).

\section{Seasonal distribution and phenological trends}

The vine mealybug displays a clear pattern of vertical seasonal movement on grapevines (De Villiers, 2006). The 
largest portion of the population has been found above ground, while their presence has also been discovered on vine roots to a depth of $30 \mathrm{~cm}$ (Walton \& Pringle, 2004a). Planococcus ficus colonies consist of overlapping generations, resulting in all stages of the life cycle being present at any time of the year (Walton, 2007; Holm, 2008). Population development and vertical movement through the course of the seasons is affected by the absence or presence of natural enemies, temperature and the availability of food (Walton, 2003; Holm, 2008).

The seasonal movement of vine mealybugs is generally similar in both the northern and southern hemispheres. Populations follow similar trends that correspond to the progression of winter and summer. In South Africa, the vine mealybugs spend the winter months in colonies on the lower regions of the plant, under the bark and underground (De Villiers, 2006; Holm, 2008). The upward movement of $P$. ficus on the vine trunk begins from spring to early summer (October/November) in the southern hemisphere and in March/April in northern hemisphere countries such as Italy and Israel (Walton, 2003; Walton \& Pringle, 2004b). In both the Coachella and San Joaquin valleys of California, the upward vertical movement of mealybugs correlates with the warmer temperatures experienced during the summer months (Daane et al., 2003). So, regardless of the hemisphere in which they occur, their upward movement shows clear correspondence with the onset of the warmer summer months. Preceding such upward movement, $P$. ficus begins forming new colonies at the bases of young buds and shoots (De Villiers, 2006; Holm, 2008). From this point they move to the leaves and, by December, they are predominantly found feeding on whatever foliage is available (De Villiers, 2006; Holm, 2008). Peak populations have been observed between January and the beginning of February, when the mealybug is found infesting grape bunches, where they feed on the abundant plant sap and on the available nutrients (Walton, 2003; Holm, 2008). Conversely, the lowest population levels on foliage have been recorded during winter months (Walton, 2003). Many colonies are removed during harvest, but they return to the leaves to feed after harvest (in autumn), and continue their migration back under the bark of the stems and trunk, where they overwinter (Walton \& Pringle, 2004b; De Villiers, 2006; Holm, 2008).

Clearly, slight variations in peak and lowest population and movement times occur from year to year. During the 2002/2003 season, De Villiers and Pringle (2007) observed peak $P$. ficus infestations in the Hex River Valley in March, as opposed to such infestations that were found between the end of January and the beginning of February by Walton and Pringle (2004b). Walton (2003) recorded the percentage infestation in the Hex River, Stellenbosch and Robertson areas from 1999 to 2001, showing that peak infestations across the three areas could occur anywhere between midFebruary and March. Such variations are generally due to differing temperatures, for example, with cool early summer temperatures delaying the upward migration of the colonies and hence resulting in a delayed population peak (Walton \& Pringle, 2004b).

Despite the general seasonal movement, the largest portion of the $P$. ficus population tends to be occur on the vine trunk throughout the year (Walton, 2003; Walton, 2007). A preference for the trunk and woody branches has been observed by Walton (2007) in Stellenbosch, McGregor and Robertson in the Western Cape. Similar findings having been recorded by Cid et al. (2010) in the Galician vineyards in north-western Spain. Both Walton (2007) and Cid et al. (2010) explain that the woody sections of the vine have bark layers that provide microhabitats, giving $P$. ficus refuge and protection from natural enemies, extreme temperatures and insecticidal sprays. In addition, Walton (2007) states that old canes and trunks are also much less disturbed during harvest and pruning, while the phloem of the trunk is easily and consistently accessible to the mealybugs.

\section{Dispersal}

Mealybugs have a limited ability to move and to disperse, as females are wingless, with their movement being restricted to only minor distances (Holm, 2008). Female crawlers (first-instar nymphs) and adult males are mostly mobile and display dispersal activity. The immobility of the female adults sets in when old individuals experience the deterioration and loss of their legs (Franco et al., 2009).

Poor pruning and harvesting techniques, along with the distribution of fruit, rootstock and grafting material, are responsible for the long-distance dispersal of $P$. ficus (Holm, 2008). Other shorter-distance dispersal mechanisms include adhering to wild and domestic animals, or moving along in water and wind (Holm, 2008; Franco et al., 2009). Distribution is mostly aggregative, as crawlers tend to settle close to the females on the natal host plant (Franco et al., 2009).

\section{Economic importance}

South Africa is the second largest table grape producer in the southern hemisphere after Chile (De Villiers \& Pringle, 2007). More than $80 \%$ of South African table grape production occurs in the Western Cape, while the Eastern and Northern Cape, Mpumalanga, Limpopo and the Free State also produce grapes (Walton et al., 2009). For the 2011/2012 season, South Africa produced a total of 54.657 million cartons (at $4.5 \mathrm{~kg}$ a carton) of table grapes (South African Table Grape Industry, 2012). In 2011, South Africa was ranked eighth in the world for the total volume of production of liquid from grapes, with a total value of 1012.8 million litres being split between wine, brandy, distilled wine and grape juice production (Wines of South Africa, 2012).

Mealybugs are pests of serious economic importance, infesting various fruit crops and ornamental plants around the world (Wakgari \& Giliomee, 2003). The grape mealybugs $P$. maritimus and $P$. ficus are two key pest species that cause great economic losses in South African, Californian, Spanish, Pakistani and South American vineyards (Greiger et al., 2001; De Villiers \& Pringle, 2007; Cid et al., 2010).

Mealybug infestations contaminate grapes. Their waxy secretions, egg-sacs and honeydew production, on which sooty mould grows, result in the fruit being unmarketable as the tolerance levels for cosmetic damage in the table grape industry are very low (Greiger \& Daane, 2001; De Villiers \& Pringle, 2007; Holm, 2008). Many consignments are rejected prior to shipment as a result of infestations and phytosanitary 
concerns. The market also has legislative restrictions on the presence of insecticidal residues on fruits, making the management of such pests increasingly more complicated (De Villiers \& Pringle, 2007; Walton et al., 2009).

Serious mealybug infestations are able to inhibit the normal ripening process of grapes, causing poor taste and colour and leading to the eventual withering of grape bunches (De Villiers, 2006; De Villiers \& Pringle, 2007). Yellowing of leaves, premature leaf drop, decreased vigour and lifespan might also occur as a result of excessive feeding by the mealybugs (De Villiers, 2006; De Villiers \& Pringle, 2007; Holm, 2008).

Planococcus ficus has characteristics that make it particularly more economically damaging than other mealybug species (Haviland et al., 2005; Daane et al., 2008). Compared to $P$. maritimus, $P$. longispinus and $P$. viburni, $P$. ficus excretes far more honeydew per individual, and has a faster development time and a higher reproductive rate of more than 250 eggs produced per female. In addition to feeding on all parts of the vine throughout the season, they also have a wider host range than other mealybug species (Daane et al., 2003; Haviland et al., 2005; Daane et al., 2008).

Finally, P. ficus is a viral disease vector, which renders it a problem even when the pest occurs at low densities (Haviland et al., 2005; Holm, 2008). The vine mealybug, along with P. longispinus and P. viburni, are all vectors of grapevine leafroll-associated virus 3 (GLRaV-3) (Petersen \& Charles, 1997; Walton \& Pringle, 2004b). GLRaV-3 reduces the amount of photosynthesis that takes place, thus reducing the quality and yield of grapes by delaying sugar accumulation and ripening, while increasing the acidity levels of the grapes, making it an economically important disease of $V$. vinifera (Petersen \& Charles, 1997; Carstens, 2002; Walton \& Pringle, 2004b). Symptoms of GLRaV-3 vary, depending on the cultivar grown and on the different environmental conditions that prevail (Carstens, 2002). Leaves generally show symptoms of downward-rolled margins, green veins and red interneural discolouration (Carstens, 2002; Douglas $\&$ Kruger, 2008). More so, P. ficus is a virus vector of both Shiraz and corky-bark diseases (Walton \& Pringle, 2004b; Holm, 2008).

\section{Relationships with ants}

The trophobiotic relationship between mealybugs and honeydew-seeking ants requires attention. This relationship is one in which ants obtain carbohydrate-rich honeydew from the mealybug, providing it with protection, transport and sanitation in exchange (Mgocheki \& Addison, 2009). Thus, ants are able to exacerbate mealybug pest problems by disrupting processes of augmentative and natural biological control and by aiding in their dispersal (Phillips \& Sherk, 1991; Daane et al., 2008). In the presence of ants, mealybugs are able to consume larger quantities of plant sap than they otherwise would. Moreover, some ant species, such as the cocktail ant Crematogaster peringueyi (Emery), actually construct a shelter over P. ficus in order to provide it with protection (Franco et al., 2009; Mgocheki \& Addison, 2009). The mutualistic relationship concerned has been shown to significantly reduce the efficacy of the biological control of
P. ficus (Addison, 2002). The most common pest ant species in South African vineyards include Linepithema humile (Mayr) (Argentine ant), Anoplolepis custodiens (Smith) (common pugnacious ant) and Anoplolepis steingroeveri (Forel) (black pugnacious ant), which protect mealybugs from parasitoids such as Coccidoxenoides perminutus (Timberlake) (Addison, 2002).

Due to the above factors it therefore is important that ants also are controlled to help enhance the effectiveness of biocontrol. Such control is currently being performed by means of chemical pesticides in the form of chemical stem barriers (Mgocheki, 2008). In comparison to other methods, stem barriers have been found to be the most effective against various ant pests (Addison, 2002).

\section{Control and monitoring options Chemical control}

To date, the most common method of mealybug pest control in South Africa has been the use of chemical insecticides. Both short-residual organophosphates (e.g. mevinphos, applied during the growing season) and delayed-dormant organophosphates (e.g. chlorpyrifos, applied just before bud break in late August) are used commonly (Walton et al., 2004; Daane et al., 2006; Holm, 2008). Unfortunately, mealybugs are difficult to control chemically due to their cryptic lifestyle, which involves hiding in crevices, under the bark and on the roots, where chemicals do not reach them (Walton \& Pringle, 2004b).

Mealybugs are covered by their typical hydrophobic waxy secretions, which prevents the penetration of any water-based insecticide solutions (Franco et al., 2009). More concerning is the ability of mealybugs to rapidly build up resistance to insecticides (Flaherty et al., 1982; Walton \& Pringle, 2004b; Franco et al., 2009). The lack of selectivity of such pesticides ultimately causes an increase in pest densities. By killing natural predators, the pesticides reduce the levels of natural biocontrol agents (Wakgari \& Giliomee, 2003; Daane et al., 2006; Holm, 2008). As Mgocheki (2008) states, pesticides often kill more of the natural enemy populations than of the intended pest, allowing the pest populations concerned to recover and, in some cases, causing a secondary pest outbreak of a species that previously was not a problem.

\section{Biological control}

Classic biological control generally involves the release of an exotic, natural enemy in order to reduce and control population numbers of an introduced pest species, with the intended permanent establishment of the biological control agent (Gaugler et al., 1997; Van Lenteren et al., 2003). In contrast, inundative biological control is when large amounts of the biological control agent are released with the intention of reducing the pest population in the absence of the establishment and continuing effects of the biological control agent (Van Lenteren et al., 2003).

The most prevalent enemies of P. ficus in South Africa include Hymenopteran parasites such as C. perminutus (which is commercially produced and available for augmentative release), Anagyrus pseudococci (Girault) and Leptomastix dactylopii (Howard), and predatory Coccinellid beetles such 
as Nephus bineavatus (Mulsant), N. quadrivittatus (Mulsant) and N. angustus (Casey) (Wakgari \& Giliomee, 2003; Walton \& Pringle, 2004a, 2004b; Holm, 2008; Mgocheki \& Addison, 2009). Unfortunately, parasitoids can only attack mealybugs when they are found on exposed locations, thus they are unable to reach $P$. ficus when it is underground or hiding beneath bark or in deep crevices (Holm, 2008). To exacerbate the problem, ants interfere with parasitism and reduce parasitoid numbers by directly killing individuals (Mgocheki \& Addison, 2009). Biological control has been the primary alternative to chemical pesticide, and is considered one of the cornerstones of integrated pest management (IPM) schemes (Gaugler et al., 1997; Koppenhöfer et al., 2000).

\section{Cultural control}

Cultural methods of control are generally designed to reduce the spread of existing mealybug infestations to uninfested vineyards (Holm, 2008). Such reduction in spread can be effected by means of organising and coordinating the onfarm movement of labourers, tools and machinery (Walton \& Pringle, 2004b). The sterilisation of harvesting and pruning equipment is very important to reduce contamination (Holm, 2008). Correct summer pruning and the removal of dead and/or excess twigs, branches and leaves increases the effectiveness of insecticides, predators and parasitoids (Walton \& Pringle, 2004b). The preservation of natural surrounding vegetation is important for providing a source of natural enemies of $P$. ficus and other agricultural pests, while increasing the biodiversity of the agro-ecosystem concerned (Bowler, 2002; Walton \& Pringle, 2004b).

\section{Integrated pest management (IPM)}

Unfortunately, chemical control has proven itself incapable of ensuring $100 \%$ control of $P$. ficus, while no cultural control method can totally prevent infestations (Walton, 2007). The increasing stringencies in terms of export requirements concerning insecticide residues on produce highlight the need for a truly effective IPM control system (Walton \& Pringle, 1999). According to both Bowler (2002) and Pretty et al. (1995), IPM uses a combination of various pest control methods to try to reduce pest populations in a sustainable, non-polluting way.

IPM strategies, which can be highly effective if they are administered correctly, are recommended for the control of P. ficus (Walton \& Pringle, 2004b; Holm, 2008). Although an IPM system should complement biological control methods, the poor implementation of a single strategy can easily have negative effects on the entire IPM programme, which, unfortunately, in reality is often the case (Walton \& Pringle, 2004b; Holm, 2008). Wakgari and Giliomee (2003) mention that for IPM strategies to be successful, a degree of knowledge of the mortality levels exerted by current natural enemies, of the density and spatial interactions of natural enemies, and of the effects of other control methods on the pest species is required. The execution of tests is also required to ensure the compatibility of the various control methods used in combination in IPM systems.

\section{Monitoring}

Monitoring is essential for the successful control of a key pest species such as $P$. ficus, as it provides valuable information regarding the pest's density and presence for consultants who are trying to select the best and most viable management options (Walton et al., 2004; De Villiers, 2006; Daane et al., 2008). Direct measures, such as the visual sampling of $P$. ficus in vineyards, is a difficult, timely and labour-intensive process, and is only effective in late summer, by which time crop damage would already have occurred (Walton et al., 2004; Franco et al., 2009). As a result, a more effective monitoring system that allows for detection early in the season is needed.

A relative monitoring system using sex pheromonebased traps has proven to be a more effective tool than other systems with which to detect mealybug colonies and provide an early-warning system (Walton et al., 2004; Daane et al., 2006; Dreves \& Walton, 2010). Female mealybugs emit species-specific sex pheromones to attract males for mating (Daane et al., 2006; Franco et al., 2009). The hormone concerned is non-toxic and effective in very small quantities when used in pheromone traps, making for far easier and more efficient capture of males than the manual searching for cryptic females (Franco et al., 2009; Dreves \& Walton, 2010). The $P$. ficus sex hormone is lavandulyl senecioate, a monoterpene ester, which has been produced synthetically and tested as a monitoring tool by Millar et al. (2002) in Californian vineyards, and by Walton et al. (2004) in South African vineyards. Sex pheromones can also be used effectively not only as a monitoring tool, but also as a means of population control and reduction by means of the mass trapping of males and/or as a means of mating disruption (Daane et al., 2006; Franco et al., 2009).

\section{Entomopathogenic nematodes}

Entomopathogenic nematodes (EPNs) have been known since the 17 th century, but serious attention has only been given to using these nematodes for insect control since the 1930s (Smart, 1995). Interest in EPNs was initiated in 1929, when Glaser and Fox found grubs of the Japanese beetle, Popillia japonica (Glaser), infected with the nematode Steinernema glaseri (Steiner, 1929) (Smart, 1995; Ehlers, 2001). With the increasing development of effective, cheap chemical pesticides from the 1940s to the 1960 s, the work and discoveries of Glaser took a backseat until recently (Smart, 1995; Adams \& Nguyen, 2002). Since the negative environmental effects, decreasing effectiveness, and increase in cost of chemicals became apparent in the mid-1960s, there has been an increasing need to find biological alternatives in terms of insect pest management (Smart, 1995; Adams \& Nguyen, 2002). Subsequently, many new nematode species with biocontrol potential have been discovered, described and tested over the past decade (Adams \& Nguyen, 2002; Stock \& Hunt, 2005). The proof of such efforts is evident, with Stock and Hunt (2005) providing a key to, and the morphological diagnosis of, 11 different nematode families used in biocontrol, of which over 100 nematode species are mentioned and described.

EPNs belonging to the families Heterorhabditidae and Steinernematidae are deadly insect pathogens that play a role in the regulation of natural insect population levels, mostly in the soil (Griffin et al., 2005; Kaya et al., 1993). 
Of particular interest regarding the two families of EPNs concerned is their inundative application as a biocontrol agent for economically important insect pests (Griffin et al., 2005).

\section{Biology and life cycle}

Heterorhabditids and Steinernematids both progress though four immature stages before reaching maturity (Adams \& Nguyen, 2002). In both families, the third stage has a freeliving, non-feeding infective juvenile (IJ) or dauer (which is German for 'enduring') juvenile. The IJ is well adapted to long-term survival in the soil while waiting for, or seeking out, a host (Ehlers, 2001).

The two families differ in their modes of reproduction such that in the first generation of Heterorhabditidae there are only hermaphrodites, while males and females are produced in proceeding generations (Griffin et al., 2005). In contrast, all Steinernematid generations are amphimictic (Griffin et al., 2005). Heterorhabditids and steinernematids have obligatory symbiotic associations with bacteria of the genera Photorhabdus and Xenorhabdus respectively (Boemare, 2001; Ehlers, 2001; Griffin et al., 2005). Photorhabdus and Xenorhabdus are both gram-negative bacteria belonging to the family Enterobacteriaceae (Boemare, 2001). Steinernematid IJs retain Xenorhabdus symbionts within an intestinal vesicle, while Photorhabdus cells stick together in the anterior part of the Heterorhabditis gut (Boemare, 2001).

When encountering a suitable insect host, the IJ enters via natural openings such as the anus, mouth or spiracles (Gaugler et al., 1997; Griffin et al., 2005). Heterorhabditis can bore directly into the haemocoel through thin parts of the cuticle by means of an anterior dorsal tooth (Gaugler et al., 1997; Griffin et al., 2005). Once in the insect's haemocoel, the IJ experiences a process called 'recovery' whereby the bacterial symbionts in their gut are released (Ehlers, 2001; Griffin et al., 2005). The bacteria grow rapidly within the nutrient-rich haemolymph, while producing toxins and other metabolites that kill off the host within 24 to 48 hours after infection (Gaugler et al., 1997; Ehlers, 2001; Griffin et al., 2005). The bacteria also produce antimicrobial compounds that prevent the development of any other microbes within the cadaver, resulting in a monoxenic microcosm (Boemare, 2001). The nematodes then change into J3 juveniles, which feed on the symbiotic bacteria as well as on host tissue that is broken down by the bacteria. The development of the J4 occurs subsequently, and this then develops into adults of the first generation (Ehlers, 2001; Adams \& Nguyen, 2002). Once the adults concerned mate, the females lay eggs that hatch and moult successively through four stages, of which the fourth stage develops into adults. The process continues in this way as long as the insect cadaver supplies sufficient resources (Ehlers, 2001; Adams \& Nguyen, 2002). Such insect cadavers normally allow for the development of approximately two or three generations of EPN. Once resources are depleted, the offspring develop into thirdstage IJs, which stop feeding and incorporate the symbiotic bacteria before exiting the cadaver in search of a new host (Ehlers, 2001; Adams \& Nguyen, 2002). IJs are, however, able to survive in the soil for several months without a host (Adams \& Nguyen, 2002).

\section{Compatibility of nematodes with agrochemicals}

In an IPM system, an important factor to consider is the compatibility and interactions of EPNs with various agrochemicals (García del Pino \& Jové, 2005; Gutiérrez et al., 2008). It would be advantageous to know whether such agrochemicals as pesticides could be applied simultaneously or tank-mixed with EPNs in order to save both money and time while facilitating the EPNs in an IPM system (De Nardo \& Grewal, 2003; Koppenhöfer \& Grewal, 2005).

Many studies have been done on the effects of chemicals on EPN species such as Steinernema feltiae Filipjev 1934, Steinernema carpocapsae Weiser 1955 and Heterorhabditis bacteriophora Poinar 1976 (Rovesti \& Deseö, 1990; Head et al., 2000; Koppenhöfer et al., 2000; De Nardo \& Grewal, 2003; Alumai \& Grewal, 2004; García del Pino \& Jové, 2005; Gutiérrez et al., 2008). The compatibility of two endemic nematodes, Heterorhabditis zealandica (Poinar, 1990) and Steinernema yirgalemense (Nguyen et al., 2004) were tested with aqueous solutions of two adjuvants $(\mathrm{Nu}-$ Film-P ${ }^{\circledR}$ and Zeba ${ }^{\circledR}$ ), two biopesticides (Helicovir ${ }^{\mathrm{TM}}$ and Cryptogran $^{\mathrm{TM}}$ ) and one insecticide (Cyperphos 500 E.C. ${ }^{\circledR}$ ) by Van Niekerk (2012). The results showed that both species were compatible with the chemicals, showing no significant reduction in levels of IJ infectivity. However, $S$. yirgalemense did show a significant increase in mortality after being exposed to the various chemicals concerned. In contrast, it has been found in many other cases that IJs are compatible and that they show a relative insensitivity to a variety of chemical formulations (García del Pino \& Jové, 2005). Thus, different agrochemicals affect different EPN species in different ways, which means that the way in which each species is affected requires evaluation (Koppenhöfer \& Grewal, 2005). The different effects on IJs have been shown to be either synergistic (additive), negative in terms of IJ infectivity and persistence, or to have no effect at all on the nematode (Koppenhöfer et al., 2000; Koppenhöfer \& Grewal, 2005).

Koppenhöfer and Grewal (2005) recommend that incompatible EPNs and agrochemicals can be managed by choosing an appropriate time interval between the applications of the two agents, depending on the persistence of the chemical concerned. A period of one to two weeks is generally recommended after a chemical application before EPNs are applied (Koppenhöfer \& Grewal, 2005). Head et al. (2000) tested not only the direct effects of insecticides on $S$. feltia, but also the effects of foliar chemical residues on the IJs. The results showed that sequential, instead of simultaneous, application of EPNs and agrichemicals might often be the better choice in an IPM system.

\section{Application \\ Aerial}

The use and application of EPNs has traditionally been focused on, and they are considered most suited to, the control of soil-dwelling pests and/or the soil life stages of insects (Wilson \& Gaugler, 2004). Unfortunately, the commercial use of EPNs for above-ground insect pests has mostly been unsuccessful and plagued with problems (Lello et al., 1996; Shapiro-Ilan et al., 2006). The sensitivity of the IJs on exposed surfaces has left above-ground treatments 
highly dependent on the prevailing weather conditions, resulting in discouragingly erratic results (Gaugler, 1988). However, tests have demonstrated the potential of aerial application with certain EPN species against particular insect pests (Lello et al., 1996; Shapiro-Ilan et al., 2006; De Waal, 2008). Targeting insects living in above-ground cryptic habitats shields the IJs from lethal environmental factors, enabling some promising results (Mason et al., 1999; Shapiro-Ilan et al., 2006). Failures can be attributed mostly to the IJs' sensitivity to abiotic factors, including ultraviolet (UV) radiation, desiccation and extreme temperatures (Smits, 1996; Mason et al., 1998). Subsequently, the successful control of above-ground insect pests using EPNs remains a challenge when considering the unfavourable aerial conditions.

Suggestions have been made to minimise the negative environmental effects of foliar EPN application. As temperatures below $0^{\circ} \mathrm{C}$ and above $40^{\circ} \mathrm{C}$ are lethal to most EPNs, the water temperature used for application should fall within the range of 4 to $30^{\circ} \mathrm{C}$ (Smits, 1996; Wright et al., 2005). To avoid desiccation and to reduce the effects of the sun's UV rays, EPNs can be applied early in the morning (when there is an added bonus chance of dew) or just prior to dusk (Lello et al., 1996; Mason et al., 1999). Adjuvants can be added to the EPN spray solution. Adjuvants have been found to help reduce the impacts of desiccation and water surface tension, allowing IJs to move out of discrete spray droplets, thus increasing the number of infecting nematodes (Mason et al., 1999; Gan-Mor \& Matthews, 2003). Van Niekerk (2012) tested the effects of two adjuvants, Nu-Film- $\mathrm{P}^{\circledR}$ (a spreader or sticker) and Zeba ${ }^{\circledR}$ (an anti-desiccant), on $H$. zealandica and $S$. yirgalemense survival and infectivity. The study showed that Zeba ${ }^{\circledR}$ significantly improved the ability of $S$. yirgalemense to infect and kill $P$. citri by reducing the negative effects of desiccation in the laboratory.

Another area of application that requires consideration is the technology used. Suboptimal application methods have contributed significantly to the failure of aerial treatments (Mason et al., 1998, 1999). Different spray and spinning disc technologies have been tested, while nozzle and pump types, droplet size, spray distribution and spray pressures have been taken into consideration to enhance the success rate of aerial EPN application (Lello et al., 1996; Mason et al., 1998, 1999; Gan-Mor \& Matthews, 2003; Shapiro-Ilan et al., 2006).

\section{Soil}

Although the soil is the natural habitat for EPN, and is a more suitable target habitat, many attempts to control insects within the soil have failed (Kung et al., 1990; Shapiro-Ilan et al., 2006). Just as with aerial application, many biotic, abiotic and application technology factors need to be considered. Abiotic factors such as soil moisture (of which too much can restrict nematode movement and cause oxygen deprivation), temperature and relative humidity have varying effects on the pathogenicity and survival of different EPN species (Kung et al., 1991; Shapiro-Ilan et al., 2006). Equally, different soil textures (sand, sandy loam, clay loam and clay) have varying effects on the pathogenicity, movement and survival of different EPN species (Kung et al., 1990; Shapiro-Ilan et al., 2006). Other abiotic factors that should be taken into consideration include UV radiation and $\mathrm{pH}$ (Shapiro-Ilan et al., 2006).

Biotic antagonists in the soil that rapidly reduce applied EPN numbers include a variety of organisms, such as bacteria, protozoans, phages, nematophagous fungi, predacious mites and other free-living nematodes (Kaya, 2002).

\section{Environmental safety and entomopathogenic nematode use}

When investigating the potential use of biocontrol it is necessary to consider whether or not such agents are completely ecologically safe. Concerns include the potential effects of the biocontrol on populations and the species composition of non-target species (Bathon, 1996). In general, little is known about the effects of the introduction or augmentation of biological control agents on belowground fauna (Somasekhar et al., 2002). In addition, only a few studies have been done concerning the impact of EPNs on natural faunal communities (Bathon, 1996). Van Lenteren et al. (2003) have expressed concern that the current, popular commercial inundative biological control might, in some cases, be carried out by people who are poorly trained in risk assessment, risk identification and risk evaluation of the biological agent. Despite concerns, adverse effects of applied EPNs seem unlikely, as the population density decreases rapidly to background levels, followed by a patchy distribution of the applied EPNs due to the many acting biotic and abiotic antagonists (Bathon, 1996; Smits, 1996). Nevertheless, according to Gaugler (1988) and Ehlers (1996), EPNs have shown no mammalian pathogenicity. However, Bathon (1996) concludes that, taking into consideration the findings of laboratory tests, vertebrates cannot be included in the host range of EPNs, and that they are unaffected by the application of EPNs for pest control.

\section{Contemporary South African studies}

Unfortunately only a few studies have been done to test the efficacy of South African EPN species against insect pests. Even more so, fewer tests have been done that test the susceptibility of Pseudococcidae to EPNs. It is important that new South African species of EPN still be discovered and tested. As a precautionary policy there are strict regulations in South Africa concerning the import of exotic organisms (amendment of Act 18 of 1989 under the Agricultural Pest Act, No. 36 of 1947), which include EPNs. This prevents the import of exotic, commercially available EPNs (Malan et al., 2006; Malan et al., 2011). The concern is that exotic nematode species may have effects on nontarget organisms and possibly displace indigenous nematode species (Ehlers, 2005). Increasing numbers of new South African EPN species with biocontrol potential are being discovered, such as Steinernema citrae (Stokwe et al., 2011), Heterorhabditis safricana (Malan et al., 2008), Steinernema khoisanae (Nguyen et al., 2006), Heterorhabditis zealandica, Heterorhabditis bacteriophora and Steinernema yirgalemense (Malan et al., 2006; Malan et al., 2011).

Stokwe (2009) performed various bioassays on Pseudococcus viburni (Signoret), the obscure mealybug. In Stokwe's (2009) studies, H. zealandica was the most lethal 
of 16 different local EPN strains. Both $H$. zealandica and $S$. yirgalemense are able to complete their life cycle and reproduce within P. viburni (Stokwe \& Malan, 2010). Host size susceptibility was also tested (Fig. 2), showing that the adult and intermediate life stages are the most susceptible to EPN infection, at $78 \%$ and $76 \%$ respectively (Stokwe \& Malan, 2010). Heterorhabditis zealandica was even found to be able to enter the core of $P$. viburni-infested apples and infect the insect (Stokwe \& Malan, 2010)

Van Niekerk (2012) conducted various bioassays and field trials to determine the potential of South African EPN isolates in controlling Planococcus citri (Risso), the citrus mealybug. Tests showed that $P$. citri was most susceptible to Heterorhabditis zealandica ( $91 \%$ mortality) and $S$. yirgalemense (97\% mortality) (Van Niekerk \& Malan, 2012). Both species were able to complete their life cycles within the insect host, while $S$. yirgalemense proved to be more tolerant of lower levels of free water and was faster at locating and infecting P. citri (Van Niekerk, 2012).

\section{Sustainable agriculture}

The term 'sustainable development' in itself is contradictory and ambiguous. The concept of sustainability is popular among environmentalists, as it embraces an inclination towards the making of ecological and social changes. On the other hand, development, at face value, is of primary concern to developers (Wackernagel \& Rees, 1996; Dresner, 2002).

In 1987, the World Commission on Environment and Development (WCED) released the report known as Our Common Future (Hattingh, 2001), which included the now well-known definition of sustainable development as "development which meets the needs of the present without sacrificing the ability of future generations to meet their needs" (Dresner, 2002). The definition can easily be extended to the agricultural sector by simply replacing the word 'development' with the word 'agriculture'.

Considering that agriculture occupies approximately 25 to $37 \%$ of the world's land area (Avery, 1999), the adoption of new pest control methods within our agricultural systems that conserve and incorporate biodiversity might potentially benefit the natural environment and the agricultural sector. Recognising such potential might be a step forward in shifting towards sustainable food production and biodiversity conservation. Sadly, there is little evidence of the global adoption of sustainable agricultural practices (Bowler, 2002). Chemical pesticides and fertilisers tend to diminish the soil's fertility and to harm many non-target biota (Lapkin, 1999). Development and cultivation have led to irreversible losses in terms of biodiversity, while habitat destruction has been, and still is, the leading cause of species extinction (Pimm \& Raven, 2000).

With current extinction rates, and levels of biodiversity and ecosystem service loss, a concerted effort should be made to change agricultural methods so as to contribute towards the alleviation of the global problem. The current rise of interest in, and increase in the number of investigations into, the use of EPNs within an IPM scheme is a positive move towards reducing chemical pesticide use in the pursuit of sustainable agriculture.

\section{LITERATURE CITED}

Adams, B.J. \& Nguyen, K.B., 2002. Taxonomy and systematics. In: Gaugler, R. (ed). Entomopathogenic nematology. CAB International, Wallingford, UK. pp. $1-28$.

Addison, P., 2002. Chemical stem barriers for the control of ants (Hymenoptera: Formicidae) in vineyards. S. Afr. J. Enol. Vitic. 23, 1-8.

Alumai, A. \& Grewal, P.S., 2004. Tank-mix compatibility of the entomopathogenic nematodes, Heterorhabditis bacteriophora and Steinernema carpocapsae, with selected chemical pesticides used in Turfgrass. Biocontrol. Sci. Techn. 14, 725-730.

Avery, D.T., 1999. Intensive farming and biotechnology: saving people and wildlife in the $21^{\text {st }}$ century. In Tansey, G. \& D'Silva, J. (eds). The meat business. London: Earthscan Publications Ltd. pp. $15-22$.

Bathon, H., 1996. Impact of entomopathogenic nematodes on non-target hosts. Biocontrol. Sci. Technol. 6, 421-434.

Ben-Dov, Y. \& Miller, D.R., 2012. ScaleNet: A database of scale insects of the world. [Available online at http://www.sel.barc.usda.gov/scalecgi/ chklist.exe?Family=Pseudococcidae\&genus $=]$

Boemare, N., 2001. Interactions between the partners of entomopathogenic bacterium nematode complexes, Steinernema-Xenorhabdus and Heterorhabditis-Photorhabdus. Nematol. 4, 601-603.

Bowler, I., 2002. Developing sustainable agriculture. Geography 87, 205212 .

Carstens, R., 2002. Vineyard viruses: leafroll overview. Winetech. [Available online at http://www.winetech.co.za/ news_leafroll.php]

Cid, M., Pereiro, S., Cabaleiro, C. \& Segura, A., 2010. Citrus mealybug (Hemiptera: Pseudococcidae) movement and population dynamics in an arbor-trained vineyard. Econ. Entomol. 103, 619-630.

Daane, K.M., Bently, W.J., Walton, V.M., Malakar-Kuenen, R., Millar, J.G., Ingels, C., Weber, E. \& Gispert, C., 2006. New controls investigated for vine mealybug. Calif. Agr. 60, 31-38.

Daane, K.M., Cooper, M.L., Triapitsyn, S.V., Walton, V.M., Yokota, G.Y., Haviland, D.R., Bentley, W.J., Godfrey, K. \& Wunderlich, L.R., 2008. Vineyard managers and researchers seek sustainable solutions for mealybugs, a changing pest complex. Calif. Agr. 62, 167-176.

Daane, K.M., Malakar-Kuenen, R., Guillen, M., Bentley, W.J., Bianchi, M. \& Gonzalez, D., 2003. Abiotic and biotic pest refuges hamper biological control of mealybugs in California vineyards. $1^{\text {st }}$ International Symposium on Biological Control of Arthropods, Honolulu. [Available online at http:// www.bugwood.org/arthropod/day5/ daane.pdf]

Daane, K.M., Middleton, M.C., Sforza, R., Cooper, M.L., Walton, V.M., Walsh, D.B., Zaviezo, T. \& Almeida, R.P.P., 2011. Development of a multiplex PCR for identification of vineyard mealybugs. Mol. Ecol. Evol. 40, 1595-1603.

De Nardo, E.A.B. \& Grewal, P.S., 2003. Compatibility of Steinernema feltiae (Nematoda: Steinernematidae) with pesticides and plant growth regulators used in glasshouse plant production. Biocontrol. Sci. Technol. $13,441-448$.

De Villiers, M., 2006. Development of a pest management system for table grapes in the Hex River Valley. PhD dissertation, Department of Conservation Ecology and Entomology, Stellenbosch University, Private Bag X1, 7602 Matieland (Stellenbosch), South Africa.

De Villiers, M. \& Pringle, K.L., 2007. Seasonal occurrence of vine pests in commercially treated vineyards in the Hex River Valley in the Western Cape province, South Africa. Afr. Entomol. 15, 241-260. 
De Waal, J., 2008. Entomopathogenic nematodes (Rhabditida: Steinernematidae \& Heterorhabditidae) for the control of the codling moth, Cydia pomonella (L.) under South African conditions. MSc thesis, Department of Conservation Ecology, Stellenbosch University, Private Bag X1, 7602 Matieland (Stellenbosch), South Africa.

Douglas, N. \& Kruger, K., 2008. Transmission efficiency of grapevine leafroll-associated virus 3 (GLRaV-3) by the mealybugs Planococcus ficus and Pseudococcus longispinus (Hemiptera: Pseudococcidae). Plant Pathol. $122,207-212$

Dresner, S., 2002. The principles of sustainability. Earthscan Publications Ltd, London, UK.

Dreves, A.J. \& Walton, V.M., 2010. Trapping and identifying mealybugs in Oregon vineyards. Extension Service, Oregon State University Department of Agriculture. [Available online at http://ir.library.oregonstate.edu/xmlui/ bitstream/handle/1957/13751/em8998.pdf?sequence=1]

Ehlers, R., 1996. Current and future use of nematodes in biocontrol: practice and commercial aspects with regard to regulatory policy issues. Biocontrol. Sci. Technol. 6, 303-316.

Ehlers, R., 2001. Mass production of entomopathogenic nematodes for plant protection. Appl. Microb. Technol. 56, 623-633.

Ehlers, R., 2005. Forum on safety and regulation. In: Grewal, P.S., Ehlers R-U. \& Shapiro-Ilan, D.I. (eds). Nematodes as biocontrol agents. CAB International, Wallingford, UK. pp. $107-114$

Flaherty, D.L., Peacock, W.L., Bettiga, L. \& Leavitt, G.M., 1982. Chemicals losing effect against grape mealybug. Calif. Agr. 36, 6 .

Franco, J.C., Zada, A. \& Mendel, Z., 2009. Novel approaches for the management of mealybug pests. In: Ishaaya, I. \& Horowitz, A.R. (eds). Biorational control of arthropod pests: Application and resistance management. Springer Science, New York. pp. 233 - 278.

Gan-Mor, S. \& Matthews, G.A., 2003. Recent developments in sprayers for application of biopesticides - an overview. Biosyst. Eng. 84, 119-125.

García del Pino, F. \& Jové, M., 2005. Compatibility of entomopathogenic nematodes with Fipronil. J. Helminthol. 79, 333-337.

Gaugler, R., 1988. Ecological considerations in the biological control of soil-inhabiting insects with entomopathogenic nematodes. Agr. Ecosyst. Environ. 24, 351-360

Gaugler, R., Lewis, E. \& Stuart, R.J., 1997. Ecology in the service of biological control: the case of entomopathogenic nematodes. Oecologia 9 , 483-489.

Greiger, C.A. \& Daane, K.M., 2001. Seasonal movement and distribution of the grape mealybug (Homoptera: Pseudococcidae): developing a sampling program for San Joaquin Valley Vineyards. Econ. Entomol. 94, 291-301.

Greiger, C.A., Daane, K.M., Bentley, W.J., Yokota, G.Y. \& Martin, L.A., 2001. Sampling program for grape mealybugs improves pest management. Calif. Agr. 55, 19-27.

Griffin, C.T., Boemare, N.E. \& Lewis, E.E., 2005. Biology and behaviour. In: Grewal, P.S., Ehlers, R.U. \& Shapiro-Ilan, D.I. (eds). Nematodes as biocontrol agents. CABI Publishing, Wallingford, UK. pp. $47-75$.

Gutiérrez, C., Campos-Herrera, R., \& Jiménez, J., 2008. Comparative study of the selected agrochemical products on Steinernema feltiae (Rhabditida: Steinernematidae). Biocontrol. Sci. Technol. 18, 101-108.

Hattingh, J.P., 2001. Conceptualizing ecological sustainability and ecologically sustainable development in ethical terms: issues and challenges. Annale No. 2. Department of Philosophy, Stellenbosch University.

Haviland, D.R., Bentley, W.J. \& Daane, K.M., 2005. Hot water treatments for control of Planococcus ficus (Homoptera: Pseudococcidae) on dormant grape cuttings. Econ. Entomol. 98, 1109-1115.
Head, J., Walters, K.F.A. \& Langton, S., 2000. The compatibility of the entomopathogenic nematode, Steinernema feltiae, and chemical insecticides for the control of the South American Leafminer, Liriomyza huidobrensis. Biocontrol 45, 345-353.

Holm, K., 2008. Construction of a cDNA library for the vine mealybug, Planococcus ficus (Signoret). MSc thesis, Department of Conservation Ecology and Entomology, Stellenbosch University, Private Bag X1, 7602 Matieland (Stellenbosch), South Africa.

Kaya, H.K., 2002. Natural enemies and other antagonists. In: Gaugler, R. (ed). Entomopathogenic nematology. CAB International, Wallingford, UK pp. $189-199$.

Kaya, H.K., Bedding, R.A. \& Akhurst, R.J., 1993. An overview of insectparasitic and entomopathogenic nematodes. In: Bedding, R.A., Akhurst, R.J. \& Kaya, H.K. (eds). Nematodes and the biological control of insect pests. CSIRO Publications, East Melbourne, Australia. pp. 1 - 9.

Koppenhöfer, A.M. \& Grewal, P.S., 2005. Compatibility and interactions with agrochemicals and other biocontrol agents. In: Grewal, P.S., Ehlers, R.-U. \& Shapiro-Ilan, D.I. (eds). Nematode as biocontrol agents. CAB International, Wallingford, UK. pp. $363-378$

Koppenhöfer, A.M., Brown, I.M., Gaugler, R., Grewal, P.S., Kaya, H.K \& Klein, M.G., 2000. Synergism of entomopathogenic nematodes and imidacloprid against white grubs: greenhouse and field evaluation. Biol. Control. 19, 245-251.

Kriegler, P.J., 1954. 'n Bydrae tot die kennis van Planococcus citri (Risso) (Homoptera: Pseudococcidae) (in Afrikaans). MSc thesis, Stellenbosch University, Private Bag X1, 7602 Matieland (Stellenbosch), South Africa.

Kung, S., Gaugler, R. \& Kaya, H.K., 1990. Soil type and entomopathogenic nematode persistence. J. Invertebr. Pathol. 55, 401-406.

Kung, S., Gaugler, R. \& Kaya, H.K., 1991. Effects of soil temperature, moisture, and relative humidity on entomopathogenic nematode persistence. J. Invertebr. Pathol. 57, 242-249.

Lapkin, N., 1999. Organic farming. Farming Press, Tonbridge, UK.

Lello, E.R., Patel, M.N., Matthews, G.A. \& Write, D.J., 1996. Application technology for entomopathogenic nematodes against foliar pests. Crop Prot. $15,567-574$

Malan, A.P., Knoetze, R. \& Moore, S.D., 2011. Isolation and identification of entomopathogenic nematodes from citrus orchards in South Africa and their biocontrol potential against false codling moth. J. Invertebr. Pathol. $108,115-125$.

Malan, A.P., Nguyen, K.B. \& Addison, M.K., 2006. Entomopathogenic nematodes (Steinernematidae and Heterorhabditidae) from the southwestern parts of South Africa. Afr. Pl. Prot. 12, 65-69.

Malan, A.P., Nguyen, A.P., De Waal, J.Y. \& Teidt, L., 2008. Heterorhabditis safricana $\mathrm{n}$. sp. (Rhabditida: Heterorhabditidae), a new entomopathogenic nematode from South Africa. Nematology 10, 381-396.

Mason, J.M., Matthews, G.A. \& Wright, D.J., 1998. Appraisal of spinning disc technology for the application of entomopathogenic nematodes. Crop Prot. 17, 453-461

Mason, J.M., Matthews, G.A. \& Wright, D.J., 1999. Evaluation of spinning disc technology for the application of entomopathogenic nematodes against a foliar pest. J. Invertebr. Pathol. 73, 282-288.

Mgocheki, N., 2008. The relationship between ants (Hymenoptera: Formicidae), vine mealybug (Hemiptera: Pseudococcidae) and parasitoids in vineyards of the Western Cape Province, South Africa. PhD dissertation, Department of Conservation Ecology and Entomology, Stellenbosch University, Private Bag X1, 7602 Matieland (Stellenbosch), South Africa.

Mgocheki, N. \& Addison, P., 2009. Interference of ants (Hymenoptera: Formicidae) with biological control of the vine mealybug Planococcus ficus (Signoret) (Hemiptera: Pseudococcidae). Biol. Control. 49, 180-185. 
Millar, I.M., 2002. Mealybug genera (Hemiptera: Pseudococcidae) of South Africa: identification and review. Afr. Entomol. 10, 185-233.

Millar, J.G., Daane, K.M., McElfresh, J.S., Moreira, J.A., Malakar-Kuenen, R., Guillen, M. \& Bently, W.J. 2002. Development and optimization of methods for using sex pheromones for monitoring the mealybug Planococcus ficus (Homoptera: Pseudococcidae) in Californian vineyards. J. Econ. Entomol. 95, 706-714.

Nguyen, K.B., Malan, A.P. \& Gozel, U., 2006. Steinernema khoisanae n. sp. (Rhabditida: Steinernematidae), a new entomopathogenic nematode from South Africa. Nematol. 8, 157-175.

Petersen, C.L. \& Charles, J.G., 1997. Transmission of grapevine leafrollassociated closteroviruses by Pseudococcus longispinus and $P$. calceolariae. Plant Pathol. 46, 509-515.

Phillips, P.A. \& Sherk, C.J., 1991. To control mealybugs, stop honeydewseeking ants. Calif. Agr. 45, 26-28.

Picker, M., Griffiths, C. \& Weaving, A., 2002. Field guide to insects of South Africa. Struik Publishers, Cape Town, South Africa.

Pieterse, W., Muller, D.L. \& Jansen van Vuuren, B., 2010. A molecular identification approach for five species of mealybug (Hemiptera: Pseudococcidae) on citrus fruit exported from South Africa. Afr. Entomol. $18,23-28$

Pimm, S. \& Raven, P., 2000. Extinction by numbers. Nature 403, 843-844.

Pretty, J., Guijt, I., Scoones, I. \& Thompson, J., 1995. Regenerating agriculture: The agroecology of low external input and community-based development. In: Kirkby, J., O'Keefe, P. \& Timberlake L. (eds). The earthscan reader in sustainable development. Earthscan Publications Ltd., London, UK. pp. $125-145$.

Rovesti, L. \& Deseö, K.V., 1990. Compatibility of chemical pesticides with the entomopathogenic nematodes, Steinernema carpocapsae Weiser and $S$. feltiae Filipjev (Nematoda: Steinernematidae). Nematologica 36, 237-245.

Shapiro-Ilan, D.I., Gouge, D.H., Piggott, S.J. \& Fife, J.P., 2006. Application technology and environmental considerations for use of entomopathogenic nematodes in biological control. Biol. Control. 38, 124-133.

Smart, G.C., 1995. Entomopathogenic nematodes for the biological control of insects. J. Nematol. 27, 529-534.

Smits, P.H., 1996. Post-application persistence of entomopathogenic nematodes. Biocontrol. Sci. Techn. 6, 379-387.

Somasekhar, N., Grewal, P.S., De Nardo, A.B. \& Stinner, B.R., 2002. Non-target effects of entomopathogenic nematodes on the soil nematode community. J. Appl. Ecol. 39, 735-744.

South African Table Grape Industry (SATI), 2012. South African table grape industry: end of season trade newsletter. [Available online at http://www. satgi.co.za/admin/upload/pdfs]

Stock, S.P. \& Hunt, D.J., 2005. Morphology and systematics of nematodes used in biocontrol. In: Grewal, P.S., Ehlers, R.U. \& Shapiro-Ilan, D.I. (eds). Nematodes as biocontrol agents. CABI Publishing, Wallingford, UK. pp. $3-46$.

Stokwe, N.F., 2009. Entomopathogenic nematodes: characterization of a new species. Long-term storage and control of obscure mealybug, Pseudococcus viburni (Hemiptera: Pseudococcidae) under laboratory conditions. MSc thesis, Department of Conservation Ecology and Entomology, Stellenbosch University, Private Bag X1, 7602 Matieland (Stellenbosch), South Africa.

Stokwe, N.F. \& Malan, A.P. 2010. Potential control of mealybugs using entomopathogenic nematodes. S. Afr. Fruit J. 7, 38-42.

Stokwe, N.F., Malan, A.P., Nguyen, K.B., Knoetze, R. \& Teidt, L., 2011. Steinernema citrae n. sp. (Rhabditida: Steinernematidae), a new entomopathogenic nematode from South Africa. Nematol. 13, 569-587.
Van Lenteren, J.C., Babendreier, D., Bigler, F., Burgio, G., Hokkanen, H.M.T., Kuske, S., Loomans, A.J.M., Menzler-Hokkanen, I., Van Rijn, P.C.J., Thomas, M.B., Tommasini, M.G. \& Zeng, Q.Q., 2003. Environmental risk assessment of exotic natural enemies used in inundative biological control. BioControl 48, 3-38.

Van Niekerk, S., 2012. The use of entomopathogenic nematodes to control citrus mealybug, Planococcus citri (Hemiptera: Pseudococcidae) on citrus in South Africa. MSc thesis, Department of Conservation Ecology and Entomology, Stellenbosch University, Private Bag X1, 7602 Matieland (Stellenbosch), South Africa.

Van Niekerk, S. \& Malan, A.P. 2012. Potential of South African entomopathogenic nematodes (Heterorhabditidae and Steinernematidae) for control of the citrus mealybug, Planococcus citri (Pseudococcidae). J. Invert. Pathol. 111, 166-176

Wackernagel, M. \& Rees, W., 1996. Our ecological footprint: reducing human impact on the earth. New Society Publishers, Gabriola Island, BC, Canada.

Wakgari, W.M. \& Giliomee, J.H., 2003. Natural enemies of three mealybug species (Hemiptera: Pseudococcidae) found on citrus and effects of some insecticides on the mealybug parasitoid Coccidoxenoides peregrines (Hymenoptera: Encytridae) in South Africa. B. Entomol. Res. 93, 243-254.

Wakgari, W.M. \& Giliomee, J.H., 2005. Description of adult and immature females of six mealybug species (Hemiptera: Pseudococcidae) found on citrus in South Africa. Afr. Entomol. 13, 281-332.

Walton, V.M., 2003. Development of an integrated pest management system for vine mealybug, Planococcus ficus (Signoret), in vineyards in the Western Cape Province, South Africa. PhD dissertation, Department of Conservation Ecology and Entomology, Stellenbosch University, Private Bag X1, 7602 Matieland (Stellenbosch), South Africa.

Walton, V.M., 2007. Seasonal vine mealybug phenology in different grape-growing areas in the Western Cape. Wynboer Wineland Magazine. [Available on line at http://www.wineland.co.za]

Walton, V.M. \& Pringle, K.L., 1999. Effects of pesticides used on table grapes on the mealybug Parasitoid Coccidoxenoides peregrinus (Timberlake) (Hymenoptera: Encyrtidae). S. Afri. J. Enol. Vitic. 20, 31-34.

Walton, V.M. \& Pringle, K.L., 2004a. A survey of mealybugs and associated natural enemies in the vineyards in the Western Cape Province, South Africa. S. Afri. J. Enol. Vitic. 25, 23-25.

Walton, V.M. \& Pringle, K.L., 2004b. Vine mealybug, Planococcus ficus (Signoret) (Hemiptera: Pseudococcidae), a key pest in South African vineyards. A review. S. Afr. J. Enol. Vitic. 25, 54-62.

Walton, V.M., Daane, K.M. \& Pringle, K.L., 2004. Monitoring Planococcus ficus in South African vineyards with sex pheromone-baited traps. Crop Prot. 23, 1089-1096.

Walton, V.M., Kruger, K., Saccaggi, D.L. \& Millar, I.M., 2009. A survey of scale insects (Sternorryncha: Coccoidea) occurring on table grapes in South Africa. J. Insect. Sci. 9, 1-6.

Wilson, M. \& Gaugler, R., 2004. Factors limiting short-term persistence of entomopathogenic nematodes. J. Appl. Entomol. 128, 250-253.

Wines of South Africa (WOSA), 2012. Wines of South Africa: Statistics. [Available online at http://www.wosa.co.za/sa/stats_worldwide.php]

Wright, D.J., Peters, A., Schroer, S. \& Fife, J.P., 2005. Application technology. In: Grewal, P.S., Ehlers, R.-U. \& Shapiro-Ilan, D.I. (eds). Nematodes as biocontrol agents. CAB International, Wallingford, UK. pp $91-106$. 